\title{
Effects of rootstock on Iranian pistachio scion cultivars
}

\author{
Majid RAHEMI*, Vahid TAVALLALI
}

Department of Horticultura Science, Shiraz University, Shiraz, Iran

rahemi@shirazu.ac.ir
${ }^{*}$ Correspondence and reprints

Received 4 October 2006 Accepted 29 April 2007

Fruits, 2007, vol. 62, p. 317-323 (C) 2007 Cirad/EDP Sciences All rights reserved DOI: 10.1051/fruits:2007027 www.fruits-journal.org

RESUMEN ESPAÑOL, p. 323

\section{Effects of rootstock on Iranian pistachio scion cultivars.}

Abstract - Introduction. Research was conducted at the Pistachio Research Institute in Rafsanjan, Iran, to evaluate the effects of 'Badami' (Pistacia vera L.), 'Sarakhs' (wild P. vera) and 'Beneh' (P. mutica F. \& M.) seedling rootstocks on the nut quality of 'Owhadi', 'Kalleh-ghuochi' and 'Ahmad-aghaie' pistachio cultivars. Twenty-year-old trees of these nine rootstock/ scion combinations were used in a two-year study done in 2003 and 2004. Materials and methods. Growth parameters [trunk cross-sectional area (TCA), tree height, canopy diameter, shoot growth, leaf area and number of suckers], yield parameters (cumulative yield and yield efficiency), and nut quality (blankness, splitting, nuts per ounce and weight of 100 nuts) were measured. Results and discussion. TCA was significantly lower on 'Sarakhs' rootstock than on the two other rootstocks and 'Sarakhs' was the least vigorous among the tested rootstocks and gave the lowest leaf area of scion cultivars. 'Sarakhs' rootstock consistently influenced the formation of the highest number of suckers. 'Badami' rootstock allowed us to obtain the greatest cumulative production and yield efficiency, the lowest blankness of pistachio nuts, and the highest percentage of splitting of pistachio nuts. Conclusion. Our study showed that genetic variability among pistachio rootstocks may influence scion vigour, yield, extent of shell splitting, blankness and nut weight.

Iran Islamic Republic / Pistacia / rootstocks / variety trials / yields / vigour / nuts / quality

\section{Effets de porte-greffes sur des greffons de cultivars de pistachiers iraniens.}

Résumé - Introduction. Une recherche a été conduite à l'institut de recherches sur le pistachier, à Rafsanjan, Iran, pour évaluer les effets des porte-greffes 'Badami' (Pistacia vera L.), 'Sarakhs' (P. vera sauvage) et 'Beneh' (P. mutica F. \& M.) sur la qualité des noix de trois cultivars de pistachier : 'Owhadi', 'Kalleh-ghuochi' et 'Ahmad-aghaie'. La production d'arbres de 20 ans représentant ces neuf combinaisons de greffons / porte-greffes a été étudiée pendant deux années de production en 2003 et 2004. Matériel et méthodes. Des paramètres de croissance (surface de section du tronc, hauteur d'arbre, diamètre de la frondaison, croissance des arbres, surface foliaire et nombre de pousses), de rendement (rendement cumulé en noix et efficacité de rendement), et la qualité de noix (noix vides ou fendues, nombre de noix par once, poids de 100 noix) ont été mesurés. Résultats et discussion. La surface de section du tronc a été significativement inférieure pour les cultivars greffés sur le porte-greffe 'Sarakhs' que sur les deux autres porte-greffes et 'Sarakhs' a été le moins vigoureux parmi les portegreffes considérés ; il a induit la plus faible surface foliaire aux cultivars utilisés comme greffon. Le porte-greffe 'Sarakhs' a influencé la formation du nombre le plus élevé de pousses. Le porte-greffe 'Badami' a permis d'obtenir la plus grande efficacité de rendement et le meilleur rendement cumulé, le moins de pistaches vides, et le plus fort taux de pistaches fendues. Conclusion. Notre étude a montré que la variabilité génétique des porte-greffes de pistachiers peut influencer la vigueur, le rendement, le taux de coquilles fendues, le taux de coquilles vides et la production de noix par le greffon.

Iran République islamique / Pistacia / porte-greffe / essai de variété / rendement / vigueur / noix / qualité 


\section{Introduction}

Pistachio trees which were grown on different rootstocks exhibit dramatic differences in vegetative growth. Pistachio seedling rootstocks from different species or hybrids have been reported to significantly affect the vigour and nutrient status of the tree, early nut production, alternate bearing, soilborne diseases, cold and salt tolerance, blank nut production and degree of shell splitting [1-4].

Iranian pistachios grow primarily on five seedling rootstocks: two species (Pistacia mutica F. \& M. and P. khinjuk), one wild Pistacia vera ( $P$. vera 'Sarakhs') and two hybrids ('Badami-Riz' and 'Ghazvini').

Pistacia mutica F. \& M. is a wild species indigenous to Iran [5, 6] and it corresponds to $P$. atlantica Desp. or is a subspecies of this taxon [7, 8]. P. khinjuk is another wild species indigenous to Iran, growing along with P. mutica in the Alpine area, and at low altitudes and in warmer areas as well [9]. Wild Pistacia vera 'Sarakhs' is the progenitor of the cultivated pistachio and the primary wild gene pool of the crop. The distribution of 'Sarakhs' is centred in the northern part of the Khurasan district in Iran. 'Badami-Riz' and 'Ghazvini' are two hybrids of cultivated $P$. vera. The effects of these rootstocks on growth characteristics, quality and yield of Iranian pistachio cultivars have not been fully evaluated. The purpose of our study was to assess the effects of rootstocks on growth characteristics, yield, cropping efficiency and quality of cultivated pistachio in Iran.

\section{Materials and methods}

Our experiment was conducted in 2003 and 2004 at the Pistachio Research Institute in Rafsanjan, Iran. The soil was a sandy loam. Twenty-year-old trees of the commercial cultivars 'Kaleh-ghuochi', 'Owhadi' and 'Ahmad-aghaie' were budded on each of the three different rootstocks 'Badami' (P. vera L.), 'Sarakhs' (wild $P$. vera) and 'Beneh' (P. mutica F. \& M.). The trees were trained to an open-centre system, and spaced at $4 \mathrm{~m} \times 7 \mathrm{~m}$. A split-plot experiment was used in randomised complete block design with three replications and two trees in each replication. The three commercial cultivars (scions) were the main plot and the three rootstocks were assigned to subplots within each main plot. Two similar branches in the north and south of each tree were selected to determine yield and nut characteristics.

\subsection{Tree growth measurements}

Trunk girths were measured during the dormant season $5 \mathrm{~cm}$ above the graft union, and trunk cross-sectional area (TCA) was calculated. In 2003 and 2004, tree vigour was also estimated, based on tree height and canopy volume, to assess the correlation with TCA. Tree crown volume was calculated using measurements of tree height and lateral spread. Leaf area was measured by leaf area meter ( $\Delta$ T Device, England); shoot length and number of crown suckers were determined at the end of the growing season.

\subsection{Flower bud and fruit set}

At full bloom, the number of growing flower buds, initial set and final fruits per trunk cross-sectional area were recorded on each selected branch. Average initial and final fruit set per flower cluster were calculated by the formula: [number of fruits per branch / number of flower clusters per branch].

Initial and final fruit sets were recorded 2 and 8 weeks after full bloom.

\subsection{Yield and nut characteristics}

Fruit yield per branch cross-sectional area, weight of 100 nuts, number of nuts per ounce, percentage of splitting and blankness were recorded at harvest time for both years of the experiment. Cumulative yield per tree and yield efficiency (cumulative yield in $\mathrm{kg}$ per trunk cross-sectional area) of each scion / rootstock combination were computed from the average yield of two branches per tree. 
Table I.

Effects of three rootstocks on tree height, canopy volume and trunk cross-sectional area (TCA) of three pistachio cultivars (combined data of 2 years, 2003 and 2004) (Iran).

\begin{tabular}{|c|c|c|c|c|c|c|c|c|c|}
\hline \multirow[t]{2}{*}{ Rootstock } & \multicolumn{3}{|c|}{ 'Ahmad-aghaie’ (scion) } & \multicolumn{3}{|c|}{ 'Kalleh-ghouchi' (scion) } & \multicolumn{3}{|c|}{ ‘Owhadi’ (scion) } \\
\hline & $\begin{array}{l}\text { Tree height } \\
\text { (m) }\end{array}$ & $\begin{array}{l}\text { Canopy volume } \\
\qquad\left(\mathrm{m}^{3}\right)\end{array}$ & $\begin{array}{l}\text { TCA } \\
\left(\mathrm{cm}^{2}\right)\end{array}$ & $\begin{array}{l}\text { Tree height } \\
\text { (m) }\end{array}$ & $\begin{array}{l}\text { Canopy volume } \\
\qquad\left(\mathrm{m}^{3}\right)\end{array}$ & $\begin{array}{l}\text { TCA } \\
\left(\mathrm{cm}^{2}\right)\end{array}$ & $\begin{array}{l}\text { Tree height } \\
\text { (m) }\end{array}$ & $\begin{array}{l}\text { Canopy volume } \\
\qquad\left(\mathrm{m}^{3}\right)\end{array}$ & $\begin{array}{l}\text { TCA } \\
\left(\mathrm{cm}^{2}\right)\end{array}$ \\
\hline ‘Badami’ & $2.36 \mathrm{a}$ & $22.96 \mathrm{~b}$ & $102.79 \mathrm{~b}$ & $2.12 \mathrm{a}$ & $17.04 \mathrm{a}$ & $86.59 \mathrm{~b}$ & $2.35 \mathrm{a}$ & $25.22 \mathrm{a}$ & $120.37 \mathrm{a}$ \\
\hline 'Sarakhs’ & $2.09 \mathrm{a}$ & $19.21 \mathrm{c}$ & $81.39 \mathrm{c}$ & $2.09 \mathrm{a}$ & $14.38 \mathrm{~b}$ & $76.36 \mathrm{c}$ & $2.32 \mathrm{a}$ & $22.77 \mathrm{~b}$ & $102.07 b$ \\
\hline ‘Beneh’ & $2.53 \mathrm{a}$ & $30.84 \mathrm{a}$ & $116.90 \mathrm{a}$ & $2.21 \mathrm{a}$ & $17.99 \mathrm{a}$ & $131.10 \mathrm{a}$ & $2.34 \mathrm{a}$ & $24.18 \mathrm{ab}$ & $119.60 \mathrm{a}$ \\
\hline
\end{tabular}

Data in the same column followed by the same letter are not significantly different. Mean separation by LSD at the $5 \%$ level.

\section{Table II.}

Effects of three rootstocks on leaf area, shoot growth, and number of suckers of three pistachio cultivars (combined data of 2 years, 2003 and 2004) (Iran).

\begin{tabular}{lccccccccc} 
Rootstock & \multicolumn{3}{c}{ 'Ahmad-aghaie' (scion) } & \multicolumn{2}{c}{ 'Kalleh-ghouchi' (scion) } & \multicolumn{3}{c}{ 'Owhadi' (scion) } \\
& $\begin{array}{c}\text { Leaf area } \\
\left(\mathrm{cm}^{2}\right)\end{array}$ & $\begin{array}{c}\text { Shoot growth } \\
(\mathrm{cm})\end{array}$ & $\begin{array}{c}\text { No. of } \\
\text { suckers }\end{array}$ & $\begin{array}{c}\text { Leaf area } \\
\left(\mathrm{cm}^{2}\right)\end{array}$ & $\begin{array}{c}\text { Shoot growth } \\
(\mathrm{cm})\end{array}$ & $\begin{array}{c}\text { No. of } \\
\text { suckers }\end{array}$ & $\begin{array}{c}\text { Leaf area } \\
\left(\mathrm{cm}^{2}\right)\end{array}$ & $\begin{array}{c}\text { Shoot growth } \\
(\mathrm{cm})\end{array}$ & $\begin{array}{c}\text { No. of } \\
\text { suckers }\end{array}$ \\
'Badami' & $108.79 \mathrm{ab}$ & $11.17 \mathrm{a}$ & $3.71 \mathrm{ab}$ & $79.29 \mathrm{~b}$ & $8.30 \mathrm{a}$ & $1.50 \mathrm{~b}$ & $99.65 \mathrm{~b}$ & $13.81 \mathrm{a}$ & $3.08 \mathrm{a}$ \\
'Sarakhs' & $96.74 \mathrm{~b}$ & $7.16 \mathrm{ab}$ & $6.01 \mathrm{a}$ & $82.02 \mathrm{~b}$ & $4.22 \mathrm{a}$ & $4.46 \mathrm{a}$ & $95.51 \mathrm{~b}$ & $7.89 \mathrm{~b}$ & $4.08 \mathrm{a}$ \\
'Beneh' & $141.97 \mathrm{a}$ & $6.18 \mathrm{~b}$ & $1.16 \mathrm{~b}$ & $117.68 \mathrm{a}$ & $4.64 \mathrm{a}$ & $0.83 \mathrm{~b}$ & $135.23 \mathrm{a}$ & $9.60 \mathrm{ab}$ & $2.58 \mathrm{a}$
\end{tabular}

Data in a same column affected by a same letter $a, b$ or $c$ are not significantly different. Mean separation by LSD at $5 \%$ level.

\subsection{Data analysis}

Combined data of two years (2003-2004) for all the characteristics measured were analysed using SAS statistical software. Treatment means were compared using the Least Significant Difference (LSD, $P=0.05$ ). Excel software was used for regression analysis.

\section{Results and discussion}

\subsection{Tree vigour}

Tree growth, as measured by trunk crosssectional area (TCA), was significantly affected by the rootstock (table I). TCA was significantly lower for cultivar scions grafted on 'Sarakhs' rootstock. 'Badami' rootstock gave intermediate results in vigour. TCA and canopy volume determination (table I) confirmed that 'Sarakhs' rootstock was the least vigorous among the three tested rootstocks.
In Italy, 'Bianca' was budded onto eight in vitro-propagated clonal rootstocks and one seedling rootstock, and annual variation in tree growth was determined as TCA. It was found that the 'Bianca' pistachio cultivar on the 'Integerrima' clone 2 grew significantly better than 'Bianca' with 'Terebinthus' $[9,10]$, and that, as the tree matures, differences in tree growth rates tend to decrease [10]. In our present study, the trees were over-mature and the differences in tree growth probably did not change very much.

Leaf area of scions was the lowest on 'Sarakhs', intermediate on 'Badami' and the highest on 'Beneh' rootstock and the differences among rootstocks were significant at the $5 \%$ level (table II). 'Sarakhs' rootstock consistently had the highest number of suckers. 'Badami' was the next one, followed by 'Beneh' rootstock.

Little published data exists on the variation in suckering and leaf area among individual pistachio trees as influenced by 
Table III.

Effects of rootstock on number of flower buds, initial fruit-set and final fruit-set of three pistachio cultivars (combined data of 2 years 2003 and 2004) (Iran).

\begin{tabular}{|c|c|c|c|c|c|c|c|c|c|}
\hline \multirow[t]{2}{*}{ Rootstock } & \multicolumn{3}{|c|}{ 'Ahmad-aghaie' (scion) } & \multicolumn{3}{|c|}{ 'Kalleh-ghouchi' (scion) } & \multicolumn{3}{|c|}{ 'Owhadi' (scion) } \\
\hline & $\begin{array}{l}\text { No. of flower } \\
\text { buds }\end{array}$ & $\begin{array}{c}\text { Initial fruit } \\
\text { set }\end{array}$ & $\begin{array}{c}\text { Final fruit } \\
\text { set }\end{array}$ & $\begin{array}{c}\text { No. of } \\
\text { flower buds }\end{array}$ & $\begin{array}{l}\text { Initial fruit } \\
\text { set }\end{array}$ & $\begin{array}{c}\text { Final fruit } \\
\text { set }\end{array}$ & $\begin{array}{l}\text { No. of flower } \\
\text { buds }\end{array}$ & $\begin{array}{l}\text { Initial fruit } \\
\text { set }\end{array}$ & $\begin{array}{c}\text { Final fruit } \\
\text { set }\end{array}$ \\
\hline ‘Badami' & $5.95 a$ & $168.33 \mathrm{a}$ & $22.11 \mathrm{a}$ & $5.43 a$ & $134.66 \mathrm{a}$ & $21.36 \mathrm{a}$ & $4.35 \mathrm{a}$ & $312.66 \mathrm{a}$ & $27.17 \mathrm{a}$ \\
\hline 'Sarakhs' & $4.54 a b$ & $110.66 \mathrm{a}$ & $11.49 \mathrm{~b}$ & $3.67 \mathrm{a}$ & $99.00 \mathrm{a}$ & $11.42 \mathrm{~b}$ & $2.64 \mathrm{a}$ & $209.00 \mathrm{~b}$ & $21.54 \mathrm{a}$ \\
\hline ‘Beneh’ & $3.21 \mathrm{a}$ & $142.33 \mathrm{a}$ & $11.02 \mathrm{~b}$ & $4.10 \mathrm{a}$ & $68.33 \mathrm{a}$ & $10.41 \mathrm{~b}$ & $3.60 \mathrm{a}$ & $153.33 b$ & $20.62 \mathrm{a}$ \\
\hline
\end{tabular}

Data in a same column affected by a same letter a, b or c are not significantly different. Mean separation by LSD at $5 \%$ level.

\section{Table IV.}

Cumulative production and yield efficiency (cumulative yield per unit of trunk cross-sectional area) of three pistachio cultivars on three different rootstocks (fruit weight without cluster, combined data of 2 years 2003 and 2004) (Iran).

\begin{tabular}{|c|c|c|c|c|c|c|}
\hline \multirow[t]{2}{*}{ Rootstock } & \multicolumn{2}{|c|}{ 'Ahmad-aghaie' (scion) } & \multicolumn{2}{|c|}{ ‘Kalleh-ghouchi' (scion) } & \multicolumn{2}{|c|}{ 'Owhadi' (scion) } \\
\hline & $\begin{array}{l}\text { Cumulative yield } \\
\text { (kg per tree) }\end{array}$ & $\begin{array}{l}\text { Yield efficiency } \\
\left(\mathrm{kg} \cdot \mathrm{cm}^{-2}\right)\end{array}$ & $\begin{array}{l}\text { Cumulative yield } \\
\text { (kg per tree) }\end{array}$ & $\begin{array}{l}\text { Yield efficiency } \\
\left(\mathrm{kg} \cdot \mathrm{cm}^{-2}\right)\end{array}$ & $\begin{array}{l}\text { Cumulative yield } \\
\text { (kg per tree) }\end{array}$ & $\begin{array}{l}\text { Yield efficiency } \\
\left(\mathrm{kg} \cdot \mathrm{cm}^{-2}\right)\end{array}$ \\
\hline ‘Badami' & $57.56 \mathrm{a}$ & $0.56 \mathrm{a}$ & $34.64 \mathrm{a}$ & $0.40 \mathrm{a}$ & 58.98 a & $0.51 \mathrm{a}$ \\
\hline 'Sarakhs' & $23.60 \mathrm{~b}$ & $0.29 \mathrm{~b}$ & $24.43 \mathrm{a}$ & $0.32 \mathrm{a}$ & $38.78 \mathrm{~b}$ & $0.38 a b$ \\
\hline 'Beneh' & $19.87 b$ & $0.17 \mathrm{~b}$ & $36.71 \mathrm{a}$ & $0.28 \mathrm{a}$ & $32.29 \mathrm{~b}$ & $0.27 \mathrm{~b}$ \\
\hline
\end{tabular}

specific rootstocks, whether seedling or clonal. Moreno et al. [11] reported that $P$. cerasus and hybrids of this species had the highest number of root suckers. Suckers are growth units that are initiated and developed in the current season and removing them around the crown of pistachio trees is beneficial to yield [12].

\subsection{Influence on flowering and fruit set}

The number of flowers per branch crosssectional area was the greatest on 'Badami' rootstock, intermediate on 'Sarakhs' and the least on scions grafted on 'Beneh' rootstock (table III). Rootstocks can affect the number of flowers per branch cross-sectional area in several ways. They may increase the proportion of auxiliary buds in 1-year-old wood, which develops florally rather than vegetatively [15]. The combined data of the two-year study indicated that pistachio root- stocks influenced the initial and final set of scion cultivars (table III). Initial and final set per branch cross-sectional area were the greatest on 'Badami' rootstock. The final fruit set in 'Ahmad-aghaie' and 'Kallehghuochi' grafted onto 'Badami' rootstock was highly significant at the 5\% level in comparison with the other two rootstocks (table III). There are no reports related to the effect of pistachio rootstocks on flower setting of scions, but, in apple, the influence of rootstock and interstock on fruit setting was published [15].

\subsection{Cumulative production and yield efficiency}

The cumulative yields were the greatest when cultivar scions were grafted on 'Badami' rootstock. Cumulative yields were intermediate on 'Beneh' and the lowest on 'Sarakhs' rootstocks (table IV). Yield effi- 
ciency was the highest on 'Badami', and the differences were significant when compared with 'Sarakhs' and 'Beneh' rootstocks. This effect of rootstock on cumulative yield was similar to the results reported by Crane and Forde [2].

Yield efficiency, which expresses the allocation of resources between reproduction and vegetative growth, was independent of canopy volume and highly variable (tables I, II). The variability in crop production among scions budded on different rootstocks could be related to genetic and edaphic conditions [13]. The cropping potential of pistachio trees reflects the variability inherent among the rootstocks. Variation in tree performance may also be associated with adaptability of the rootstock to soil conditions, and water and nutrient availability. Inadequate soil moisture reduces shoot growth, number of flower bud formation on shoots and nut weight. A positive relationship was observed between tree height, canopy volume and trunk crosssectional area in pistachio cultivars (figures 1, 2).

\subsection{Nut quality}

Quality determination was made each year on 100 nut samples from branches on each tree. Blankness (\%) of pistachio nuts was affected by the type of rootstock. It was the lowest for cultivar scions grafted on 'Badami', intermediate on 'Beneh' and the highest on 'Sarakhs' rootstocks (table V). The

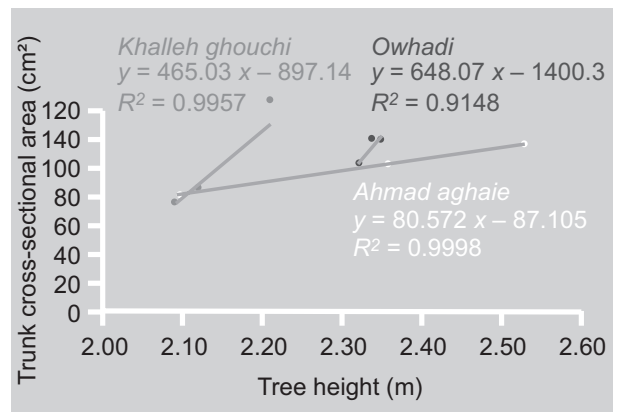

Figure 1.

Relationships between tree height and trunk crosssectional area of three pistachio scion cultivars on three rootstocks (Iran).

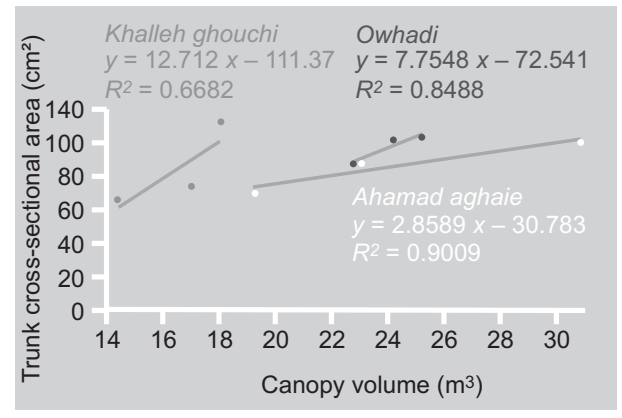

Figure 2.

Relationships between canopy volume and trunk crosssectional area of three pistachio scion cultivars on three rootstocks (Iran). splitting percentage of pistachio nuts was the highest on 'Badami' and the lowest on 'Sarakhs' rootstocks. A negative relationship was detected between percentages of blankness and splitting of pistachio nuts of cultivars (figure 3). This effect clearly showed the influence of rootstock on nut development. Shell splitting appears to be related in some way to blank production. The lower the percentage of blanks, the higher the percentage of filled nuts with split shells. The weight of 100 nuts on branches

\section{Table V.}

Effects of three rootstocks on blankness, splitting, number of nuts per ounce and weight of 100 nuts of three pistachio cultivars (combined data of 2 years 2003 and 2004) (Iran).

\begin{tabular}{|c|c|c|c|c|c|c|c|c|c|c|c|c|}
\hline \multirow[t]{2}{*}{ Rootstock } & \multicolumn{4}{|c|}{ 'Ahmad-aghaie' (scion) } & \multicolumn{4}{|c|}{ ‘Kalleh-ghouchi’ (scion) } & \multicolumn{4}{|c|}{ ‘Owhadi’ (scion) } \\
\hline & $\begin{array}{c}\text { Blankness } \\
(\%)\end{array}$ & $\begin{array}{l}\text { Splitting } \\
(\%)\end{array}$ & $\begin{array}{l}\text { No. of nuts } \\
\text { per ounce }\end{array}$ & $\begin{array}{l}\text { Weight of } \\
100 \text { nuts }\end{array}$ & $\begin{array}{c}\text { Blankness } \\
(\%)\end{array}$ & $\begin{array}{l}\text { s Splitting } \\
\text { (\%) }\end{array}$ & $\begin{array}{c}\text { No. of nuts } \\
\text { per ounce }\end{array}$ & $\begin{array}{l}\text { Weight of } \\
100 \text { nuts }\end{array}$ & $\begin{array}{c}\text { Blankness } \\
(\%)\end{array}$ & $\begin{array}{l}\text { Splitting } \\
(\%)\end{array}$ & $\begin{array}{l}\text { No. of nuts } \\
\text { per ounce }\end{array}$ & $\begin{array}{l}\text { Weight of } \\
100 \text { nuts }\end{array}$ \\
\hline ‘Badami’ & $9.91 b$ & $69.83 \mathrm{ab}$ & $28.83 \mathrm{a}$ & $131.71 \mathrm{a}$ & $6.00 \mathrm{~b}$ & $56.05 \mathrm{a}$ & $26.33 \mathrm{a}$ & $157.66 \mathrm{a}$ & $11.18 b$ & $74.09 \mathrm{a}$ & $31.25 \mathrm{a}$ & $121.00 \mathrm{a}$ \\
\hline 'Sarakhs' & $17.33 \mathrm{a}$ & $45.94 \mathrm{~b}$ & $26.65 \mathrm{a}$ & $95.68 \mathrm{~b}$ & $8.00 \mathrm{~b}$ & $46.58 \mathrm{a}$ & $25.58 \mathrm{a}$ & $110.18 b$ & $33.00 \mathrm{a}$ & $32.71 \mathrm{~b}$ & $31.08 \mathrm{a}$ & $46.44 \mathrm{c}$ \\
\hline ‘Beneh’ & $10.51 \mathrm{~b}$ & $71.16 \mathrm{a}$ & $24.08 \mathrm{a}$ & $95.89 \mathrm{~b}$ & $14.85 \mathrm{a}$ & $46.86 \mathrm{a}$ & $23.33 \mathrm{a}$ & $111.88 b$ & $14.58 \mathrm{~b}$ & $65.66 \mathrm{a}$ & $27.50 \mathrm{a}$ & $87.83 \mathrm{~b}$ \\
\hline
\end{tabular}

Data in a same column affected by a same letter a, b or c are not significantly different. Mean separation by LSD at $5 \%$ level. 
Figure 3.

Relationships between blankness and splitting of pistachio nuts of three scion cultivars on three rootstocks (Iran).

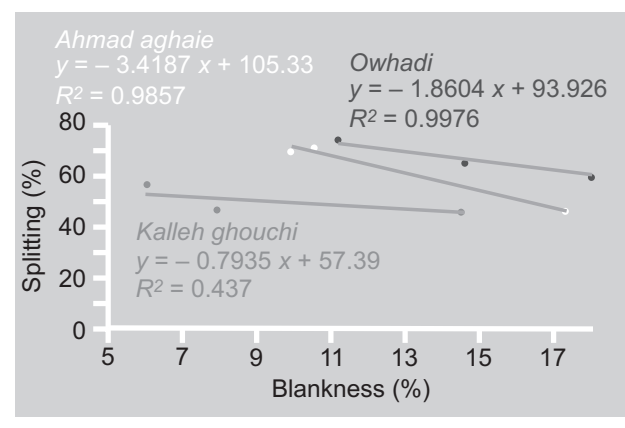

of cultivars was consistently increased by the type of rootstock (table $V$ ). No published data on nut weight among pistachio trees as influenced by specific rootstock are available. Nut-fill in pistachio is a result of synchronising blossoming of male and female flowers, pollination and fertilisation of female flowers [14]. The nut weight (28 g), which determines the number of nuts per ounce, is an important factor in pistachio marketing. In our study, rootstocks had no effect on this parameter.

\section{Conclusions}

Our data on the effects of rootstocks on characteristics of pistachio scion cultivars indicated that genetic variability among pistachio rootstocks may influence scion vigour, yield, extent of shell splitting, blankness and weight of nut production. Developing a method to elucidate this mechanism is necessary and needs further investigation.

\section{References}

[1] Ashworth L.J., Verticillium resistant rootstock research, Annu. Rep. Calif. Pist. Ind., Fresno, Calif., USA, 1985, pp. 54-56.

[2] Crane J.C., Forde H.T., Effect of four rootstocks on yield and quality of pistachio nuts, J. Am. Soc. Hortic. Sci. 101 (1976) 604-606.

[3] Crane J.C., Iwakiri B.T., Pistachio yield and quality as affected by rootstock, HortScience 21 (1986) 1139-1140.
[4] Walker R.R., Torokflavy E., Behboudian H.M., Uptake and distribution of chloride, sodium and potassium ions and growth of salt-treated pistachio, Plant Aust. J. Agric. Res. 38 (1987) 383-349.

[5] Zohary M., A monographic study of the genus Pistacia in Palestine, J. Bot. Jerus. Ser. 5 (1952) 187-228.

[6] Tabatabaee M., Pistachio and its importance in Iran, For. Serv. Press, Minist. Agric., Tehran, Iran, 1965, $160 \mathrm{p}$.

[7] Rechinger K.W., Flora des Iranshen Hochlandes und umrahmen den Cebirces, Akad. Druck-U-Verlag., Graz, Austria, 1969.

[8] Sabeti H., Forests, Trees and shrubs of Iran, Yazd Univ. Publ., 2nd ed., 1994, 875 p.

[9] Behboodi B.S., Ecological distribution study of wild pistachio for selection rootstock, Options Méditérr. Sér. A 63 (2005) 61-67.

[10] Barone F., Sottile F., Palazzolo E., Caruso T., Effect of rootstock on trunk growth and foliar mineral content in cv. Bianca pistachio (Pistacia vera L.) trees, Acta Hortic. 470 (1997) 394-401.

[11] Moreno M.A., Adrada R., Aparicio J., Betran J.A., Performance of Sunburst sweet cherry grafted on different rootstocks, J. Hortic. Sci. Biotechnol. 76 (2001) 167-173.

[12] Spann T., Beede R.H., Weinbaum S., DeJong T., Effect of rootstock on performance, shoot growth and yield component of pistachio cultivar, Kerman, Annu. Rep. Crop Year 2004-2005, Calif. Pist. Ind., Fresno, Calif., USA, 2005, pp. 101-102.

[13] Johnson R.S., Weinbaum S.A., Variation in tree size, yield, cropping efficiency and alternate bearing among 'Kerman' pistachio trees, J. Am. Soc. Hortic. Sci. 112 (1987) 942-945.

[14] Rahemi M., Asghari H., Effect of hydrogen cynamide (Dormex), volk oil and potassium nitrate on budbreak, yield and characteristics of pistachio (Pistachio vera L.), J. Hortic. Sci. Biotechnol. 79 (2004) 823-827.

[15] Webster A.D., Rootstock and interstock effects on deciduous fruit tree vigour, precocity and yield productivity, N. Z. J. Crop Hortic. Sci. 23 (1995) 373-382. 
Efectos de porta-injertos sobre los injertos de cultivares de pistacho iraníes.

Resumen - Introducción. Se llevó a cabo una investigación en el instituto de investigaciones sobre el pistacho, en Rafsanjan, Irán, con el fin de evaluar los efectos de los porta-injertos 'Badami' (Pistacia vera L.), 'Sarakhs' ( $P$. vera silvestre) y 'Beneh' ( $P$. mutica F. \& M.) sobre la calidad de las nueces de tres cultivares de pistacho: 'Owhadi', 'Kalleh-ghuochi' y 'Ahmadaghaie'. Se estudió la producción de árboles de 20 años, que representaban estas nueve combinaciones de injertos/ porta-injertos, durante dos años de producción en 2003 y en 2004. Material y métodos. Se midieron parámetros de crecimiento [superficie de sección del tronco, altura del árbol, diámetro del follaje, crecimiento de los árboles, superficie foliar y número de brotes], de rendimiento (rendimiento cumulado en nueces y eficacia de rendimiento), y la calidad de la nuez (nueces vacías o abiertas, número de nueces por onza, peso de 100 nueces). Resultados y discusión. La superficie de sección del tronco fue significativamente inferior para los cultivares injertados sobre el porta-injerto 'Sarakhs' que para los dos otros porta-injertos; y, 'Sarakhs' fue el menos vigoroso entre los porta-injertos considerados; indujo la superficie foliar más escasa en los cultivares empleados como injerto. El portainjerto 'Sarakhs' influyó la formación del número más elevado de brotes. El porta-injerto 'Badami' permitió la mayor obtención de eficacia de rendimiento, así como el mejor rendimiento cumulado, el menor número de pistachos vacíos, y el índice más alto de pistachos abiertos. Conclusión. Nuestro estudio mostró que la variabilidad genética de los porta-injertos de pistacho puede influir en el vigor, el rendimiento, el índice de cáscaras abiertas, el índice de cáscaras vacías así como en la producción de nueces por el injerto.

Iran República Islámica / Pistacia / portainjertos / ensayos de variedades / rendimiento / vigor / nuez / calidad 